\title{
Tea consumption and risk of bladder cancer: a meta-analysis
}

\author{
Jie Qin', Bo Xie², Qiqi Mao', Debo Kong ${ }^{1}$, Yiwei Lin ${ }^{1}$ and Xiangyi Zheng ${ }^{1 *}$
}

\begin{abstract}
Background: Tea consumption has been reported to be associated with an decreased risk of several types of cancers. However, the results based on epidemiological studies on the association of tea consumption with bladder cancer were inconsistent. This meta-analysis was undertaken to evaluate the relationship between tea consumption and bladder cancer risk.
\end{abstract}

Methods: Eligible studies were retrieved via both computer searches and review of references. The summary relative risk (RR) with 95\% confidence interval (Cl) was calculated.

Results: Twenty three studies met the inclusion criteria of the meta-analysis. No association with bladder cancer was observed in either overall tea consumption group ( $\mathrm{OR}=0.94,95 \% \mathrm{Cl} 0.85-1.04)$ or subgroups stratified by sex, study design, geographical region or tea types.

Conclusions: Our findings did not support that tea consumption was related to the decreased risk of bladder cancer.

Keywords: Green tea, Black tea, Bladder neoplasms, Meta-analysis

\section{Background}

In the United States, an estimated 70,530 new cases of bladder cancer will be diagnosed and approximately 14,680 deaths were attributed to bladder cancer in 2010 [1]. Bladder cancer is the most expensive cancer to survey and treat because of the need for frequent interval cystourethroscopy, urine cytology and radiological evaluations [2]. Therefore, more and more attention has been given to chemoprevention. Cancer chemoprevention is defined as the use of natural, synthetic, or biologic chemical agents to reverse, suppress, or prevent carcinogenic progression to invasive cancer. Bladder cancer has a protracted course of progression and may be ideal for chemoprevention strategies [3].

Tea, derived from the plant Camellia sinensis, is one of the most common beverages consumed worldwide, especially in China. Multiple lines of evidence support a protective effect of tea on various cancers [4]. The emperor of China, ShenNung, is credited with first describing the therapeutic effects of tea in 2737 BC [5]. Studies

\footnotetext{
* Correspondence: urology@yeah.net

${ }^{1}$ Department of Urology, First Affiliated Hospital, Zhejiang University School of Medicine, Hangzhou 310003, Zhejiang Province, China

Full list of author information is available at the end of the article
}

conducted on cell-culture systems and animal models show that tea or the active ingredient in tea, polyphenols, could afford protection against a variety of cancer types [4]. However, the results based on epidemiological studies on the association of tea consumption with bladder cancer were inconsistent. A meta-analysis conducted in 2001 suggested the consumption of tea seems not to be related to an increased risk of urinary tract cancer [6].

The purpose of the present study was to update and quantitatively assess the association between tea consumption and the risk of bladder cancer by summarizing the results of published cohort and case-control studies. We also sought to address the unresolved issue of whether this relationship differs across the tea type.

\section{Results}

In total, we identified 35 papers examining the risk of bladder cancer with tea consumption published between 1966 and December 2011, and these were reviewed by 2 authors. We found no relevant non-English language papers in this field. Six studies were excluded because of insufficient information to compute its relative risk (RR) and $95 \%$ confidence interval $(\mathrm{CI})[7-9]$, or a summary

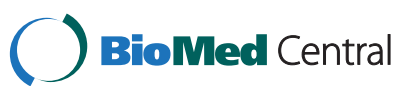


odds ratio (OR) adjusted for at least age, sex and smoking [10-12]. Six studies were excluded because they were found to be subsets of other studies or have overlapping data and were excluded [13-18]. Thus, 23 studies [19-41] were included in the meta-analysis on the association of tea consumption with bladder cancer risk. There were six cohorts $[26,29,31,33,38,40]$ and seventeen casecontrol studies; nine of these were population-based $[19-21,23,27,30,34,37,41]$ and eight were hospital-based case-control studies [22,24,25,28,32,35,36,39]. Of the twenty-three studies, seventeen were conducted in Western countries [17,20-27,29,30,32-34,36,37,40,41], and six were conducted in Asia [19,28,31,35,38,39]. Only eight articles reported association between consumption of specific tea types (green or black tea) and the risk of bladder cancer [19,23,25,26,31,35,38,39]. Information on tea consumption was obtained by interview, selfadministered questionnaire or both techniques.

Table 1 presents the basic characteristics of each study included in our meta-analysis. Of the seventeen casecontrol studies, most studies found no significant association between tea consumption and bladder cancer, whereas four studies reported significantly increased risks $[20,28,36,41]$, and three found inverse associations $[19,30,35]$. Of the six cohort studies, five reported no significant association between tea consumption and bladder cancer $[26,29,31,38,40]$, whereas one found significantly decreased risk [33].

Figure 1 plots the pooled risk estimates for overall tea consumption by study design. When all these studies were analyzed together, no association was observed for tea consumption with bladder cancer (OR 0.94, 95\% CI $0.85,1.04)$ and the summary ORs were similar across study design and source of the controls in case-control studies. No statistically significant heterogeneity was observed when all the studies were analyzed together. However, we noted some heterogeneity in the populationbased case-control studies $\left(\mathrm{I}^{2} 58.2 \%, P=0.014\right)$. After excluding one study by Slattery et al. [41], which reported the highest point estimates, the $P$-value for heterogeneity in the subgroup was no longer statistically significant $\left(\mathrm{I}^{2} 15.2 \%, P 0.311\right)$, and the summary OR was not significantly changed (OR $0.94,95 \%$ CI $0.83,1.05$ ). There was no indication of publication bias from the Begg funnel plot (Figure 2).

The results of subgroup analyzes by sex (men and women), geographical region (US/Canada, Europe, Uruguay and Asia) and tea type (green tea and black tea) are shown in Table 2. The OR estimates from subgroup analysis varied little, showing tea consumption was not associated with the likelihood of bladder cancer when separately analyzed by sex, geographical regions or tea type. In the subgroup analysis by tea type (Figure 3), we noted that green tea or black tea consumption was not associated with bladder cancer risk (OR 0.97, 95\% CI $0.73,1.21$; OR $0.79,95 \%$ CI $0.59,0.99)$. There was weak heterogeneity among studies for black tea. We performed a sensitivity analysis, which removed one study at a time. This analysis confirmed the stability of the results for black tea. No indication of publication bias was observed from either with the Egger or Begg test in any subgroup.

\section{Discussion}

There has been considerable interest in the possible impact of tea consumption on bladder cancer risk due to the modifiable nature of tea consumption. In this metaanalysis of epidemiological studies of the association between tea and risk of bladder cancer including six cohorts and seventeen case-control studies, we found that tea consumption was not associated with reduced risk of bladder cancer.

A previous meta-analysis by Zeegers et al. [6] found no association between tea consumption and bladder cancer risk. The authors reported that the consumption of tea seems not to be related to an increased risk of urinary tract cancer. Our finding is consistent with their results. However, our study included 11 studies published after 2000 that were not included in the previous meta-analysis. We pooled the OR estimates by sex (men and women), tea type (green tea and black tea), geographical region (US/Canada, Europe, Uruguay and Asia), and study design (cohort or case-control studies).

Studies conducted on cell-culture systems and animal models as well as human epidemiological studies show that tea could afford protection against a variety of cancer types. Several laboratory studies have tried to investigate the link between tea and bladder cancer. Most of tea research on bladder cancer to date has focused on the effect and mechanism of green tea. It is generally agreed that many of the chemoprevention effects of green tea are mediated by polyphenols. The major catechins in green tea are epigallocatechin-3-gallate (EGCG), epicatechin-3-gallate, epigallocatechin, and epicatechin. EGCG accounts for 50\% to $80 \%$ of catechin in green tea. Our previous study indicates that EGCG induces apoptosis in human bladder cancer T24 cells [42]. Kemberling et al. found that green tea (15\% of which are polyphenols) have shown efficacy against rat bladder cancer induced by $\mathrm{N}$-(4-hydroxybutyl)-N-bytyl-nitrosame (OH-BBN) [5]. The non-significant findings regarding the effects of tea consumption on bladder cancer in our meta-analyses contradict the results of previous experimental studies on this topic using in vitro bladder cancer cell lines and in vivo animal models. The difference between the results from experimental studies and our meta-analyses is likely to be due to the lower quantities of human tea consumption compared to the 
Table 1 Study characteristics of published cohort and case-control studies on tea consumption and bladder cancer

\begin{tabular}{|c|c|c|c|c|c|c|c|c|}
\hline $\begin{array}{l}\text { Authors and } \\
\text { year }\end{array}$ & $\begin{array}{l}\text { Study } \\
\text { design }\end{array}$ & Country & $\begin{array}{l}\text { Study } \\
\text { period }\end{array}$ & $\begin{array}{l}\text { Cases/ } \\
\text { subjects }\end{array}$ & $\begin{array}{l}\text { Anatomical } \\
\text { site of } \\
\text { urinary tract }\end{array}$ & $\begin{array}{l}\text { Tea } \\
\text { type }\end{array}$ & Variables of adjustment & $\begin{array}{l}\text { Tea drinking } \\
\text { assessment }\end{array}$ \\
\hline Ros et al. [40] & Cohort & $\begin{array}{l}\text { European } \\
\text { countries }\end{array}$ & $1992-2000$ & $513 / 233,236$ & Urinary tract & Tea & Age, sex, smoking status & Questionnaire \\
\hline \multirow[t]{2}{*}{ Hemelt et al. [39] } & \multirow[t]{2}{*}{$\mathrm{HCC}$} & \multirow[t]{2}{*}{ China } & \multirow[t]{2}{*}{$2005-2008$} & $\begin{array}{l}419 / 384 \\
\text { (green tea) }\end{array}$ & \multirow[t]{2}{*}{ Bladder } & Green tea & \multirow{2}{*}{$\begin{array}{l}\text { Age, sex, smoking status, smoking } \\
\text { frequency, and smoking duration } \\
\text { adjusted odds ratios }\end{array}$} & \multirow[t]{2}{*}{ Questionnaire } \\
\hline & & & & $\begin{array}{l}408 / 385 \\
\text { (black tea) }\end{array}$ & & Black tea & & \\
\hline \multirow[t]{2}{*}{ Kurahashi et al. [38] } & \multirow[t]{2}{*}{ Cohort } & \multirow[t]{2}{*}{ Japan } & \multirow[t]{2}{*}{$1990-2005$} & $\begin{array}{l}164 / 49,566 \\
\text { (men) }\end{array}$ & \multirow[t]{2}{*}{ Bladder } & \multirow[t]{2}{*}{ Green tea } & \multirow[t]{2}{*}{$\begin{array}{l}\text { Age, area, smoking status, alcohol } \\
\text { and coffee consumption }\end{array}$} & \multirow[t]{2}{*}{ Questionnaire } \\
\hline & & & & $\begin{array}{l}42 / 54,874 \\
\text { (women) }\end{array}$ & & & & \\
\hline
\end{tabular}

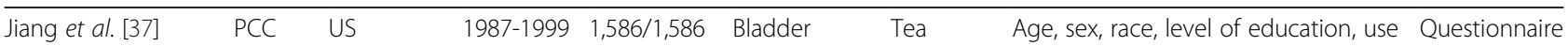
of NSAIDs, carotenoid intake, number of years as hairdresser/ barber, cigarette smoking status, duration of smoking, and intensity of smoking.

\begin{tabular}{|c|c|c|c|c|c|c|c|c|}
\hline Stefani et al. [36] & $\mathrm{HCC}$ & Uruguay & $1996-2000$ & $255 / 501$ & Bladder & Tea & $\begin{array}{l}\text { Age, sex, residence, urban/rural } \\
\text { status, education, family history of } \\
\text { bladder cancer among first-degree } \\
\text { relatives, body mass index, } \\
\text { occupation, smoking status, years } \\
\text { since quitting, number of cigarettes } \\
\text { smoked per day, maté drinking, soft } \\
\text { drink intake, milk intake, and, coffee } \\
\text { drinking }\end{array}$ & Both \\
\hline
\end{tabular}

Wakai et al. [35] HCC Japan 1994-2000 124/744 Urinary tract $\frac{\begin{array}{l}\text { Green tea } \\ \text { Black tea }\end{array} \text { cigarettes, year of first visit }}{\text { cigtion of Questionnaire }}$

\begin{tabular}{llllll}
\hline Woolcott et al. [34] PCC Canada 1992-1994 927/2118 & Bladder & Tea & $\begin{array}{l}\text { Age, sex, education level, current } \\
\text { smoking, cumulative smoking, and } \\
\text { intake of energy, calcium, fibre and } \\
\text { beer }\end{array}$ \\
\hline Znestionnaire
\end{tabular}

\begin{tabular}{|c|c|c|c|c|c|c|c|c|}
\hline Zeegers et al. [33] & Cohort & Netherland & 1986-1992 & $569 / 3,123$ & Bladder & Tea & $\begin{array}{l}\text { Age, sex, number of cigarettes/day, } \\
\text { years of cigarette smoking, and } \\
\text { coffee consumption }\end{array}$ & Questionnaire \\
\hline
\end{tabular}

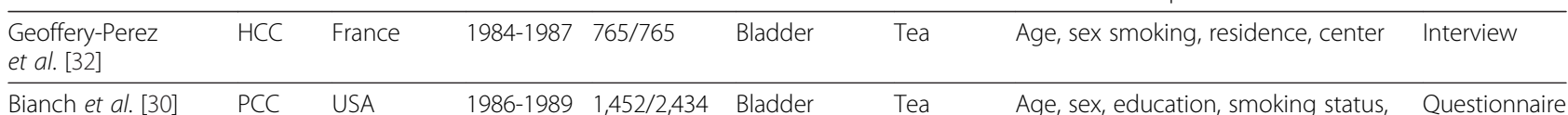
family history of bladder cancer, high risk occupation, total beverage consumption, years of chlorinated surface water, vegetable and coffee consumption

\begin{tabular}{|c|c|c|c|c|c|c|c|c|}
\hline \multirow[t]{2}{*}{ Nagano et al. [31] } & \multirow[t]{2}{*}{ Cohort } & \multirow[t]{2}{*}{ Japan } & \multirow[t]{2}{*}{ 1979-1981 } & \multirow[t]{2}{*}{$114 / 3,8540$} & \multirow[t]{2}{*}{ Bladder } & \multirow{2}{*}{$\frac{\text { Green tea }}{\text { Black tea }}$} & \multirow{2}{*}{$\begin{array}{l}\text { Age, gender, radiation dose, smoking } \\
\text { status, education level, body-mass } \\
\text { index, and calendar time }\end{array}$} & \multirow{2}{*}{ Questionnaire } \\
\hline & & & & & & & & \\
\hline Lu et al. [28] & $\mathrm{HCC}$ & Taiwan & 1996-1997 & $40 / 160$ & Bladder & Tea & $\begin{array}{l}\text { age, sex, date of admission, family } \\
\text { history, ethnicity, and smoking status. }\end{array}$ & Questionnaire \\
\hline Michaud et al. [29] & Cohort & US & 1986-1996 & $252 / 47,909$ & Bladder & Tea & $\begin{array}{l}\text { Geographic region, age, pack-years } \\
\text { of smoking, current smoking status, } \\
\text { energy intake, intake of fruits and } \\
\text { vegetables, and intake of all other } \\
\text { beverages. }\end{array}$ & Questionnaire \\
\hline Bruemmer et al. [27] & PCC & US & 1987-1990 & $262 / 405$ & Bladder & Tea & Age, sex, smoking, county & Interview \\
\hline \multirow[t]{2}{*}{ Chyou et al. [26] } & Cohort & US & 1965-1968 & $96 / 7,995$ & Urinary tract & Green tea & Age, smoking & Both \\
\hline & & & & & & $\overline{\text { Black tea }}$ & & \\
\hline Kunze et al. [25] & $\mathrm{HCC}$ & Germany & 1977-1985 & $675 / 675$ & Urinary tract & Black tea & Age, sex, smoking & Interview \\
\hline
\end{tabular}


Table 1 Study characteristics of published cohort and case-control studies on tea consumption and bladder cancer (Continued)

\begin{tabular}{|c|c|c|c|c|c|c|c|c|}
\hline D'Avanzo et al. [24] & $\mathrm{HCC}$ & Italy & 1985-1990 & $555 / 855$ & Bladder & Tea & $\begin{array}{l}\text { Age, sex, education, smoking habits, } \\
\text { alcohol drinking and exposure to } \\
\text { occupational risk }\end{array}$ & Interview \\
\hline Nomura et al. [23] & PCC & US & 1977-1986 & $261 / 522$ & Urinary tract & Black tea & $\begin{array}{l}\text { Age, sex, pack-years of cigarette } \\
\text { smoking }\end{array}$ & Interview \\
\hline Clavel et al. [22] & $\mathrm{HCC}$ & France & 1984-1987 & $690 / 690$ & Bladder & Tea & Age, sex, smoking & Interview \\
\hline Slattery et al. [18] & PCC & US & 1977-1982 & $419 / 889$ & Bladder & Tea & $\begin{array}{l}\text { Age, sex, smoking status, diabetes } \\
\text { and bladder infection }\end{array}$ & Interview \\
\hline Risch et al. [21] & PCC & Canada & 1979-1982 & $876 / 1,668$ & Bladder & Tea & $\begin{array}{l}\text { Age, sex, residence, and lifetime } \\
\text { cigarette consumption. }\end{array}$ & Interview \\
\hline Jensen et al. [20] & PCC & Denmark & 1979-1981 & $371 / 771$ & Bladder & Tea & Age, sex, smoking status, & Interview \\
\hline Ohno et al. [19] & PCC & Japan & 1976-1978 & $293 / 589$ & Urinary tract & Black tea & Age, smoking & Interview \\
\hline
\end{tabular}

PCC: population-based case-control study, HCC: hospital-based case-control study, NSAIDs: non-steroidal anti-inflammatory drugs, Both: questionnaire and interview.

doses used in experimental studies and the fact that bioavailability is an important factor for consideration.

As a meta-analysis of previously published observational studies, our study has several limitations that need to be taken into account when considering its contributions. First, our meta-analysis only included published articles. Unpublished studies were not searched for our analysis. Second, we did not include studies with insufficient information to estimate an adjusted OR, which could bring publication bias even though no significant evidence of publication bias was observed in the Egger or the Begg tests. Third, our meta-analysis is likely

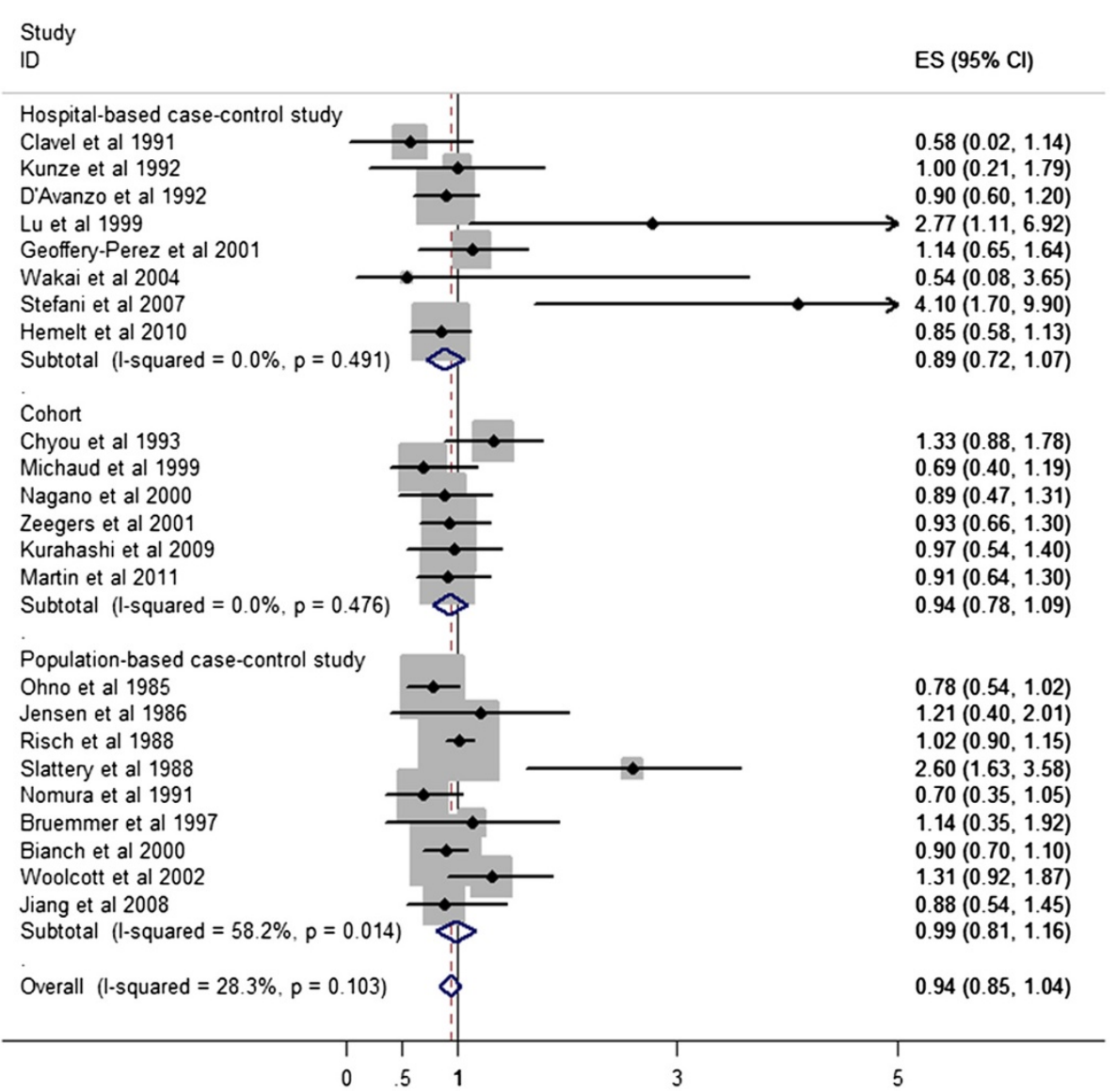

Figure $1 \mathrm{~A}$ forest plot showing risk estimates from case-control and cohort studies estimating the association between tea consumption and risk for bladder cancer. 


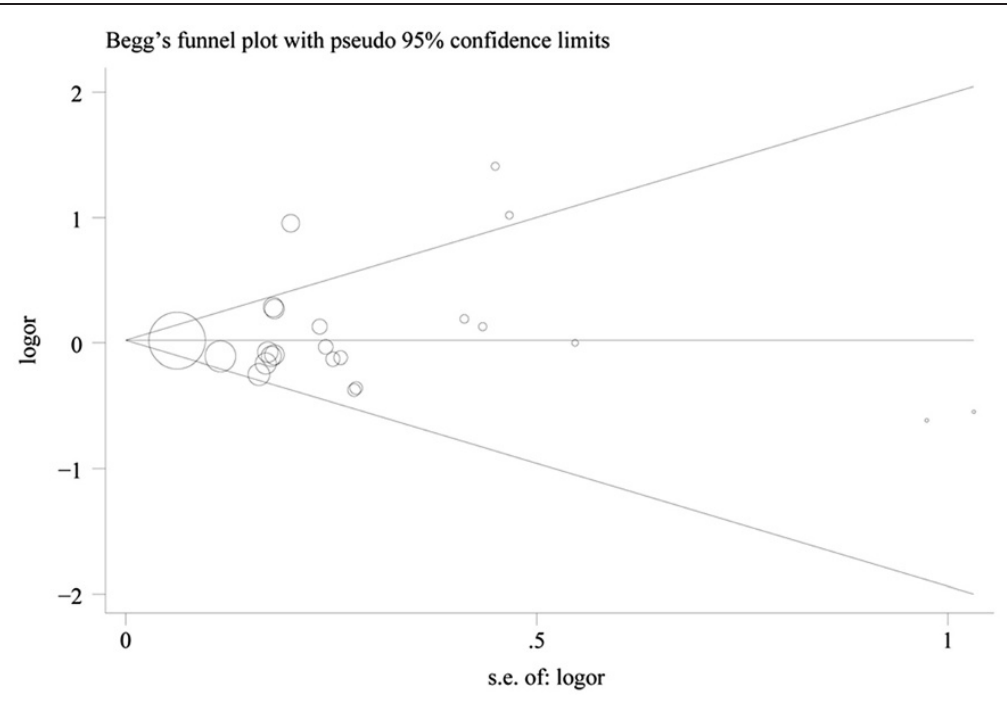

Figure 2 Funnel plot of tea consumption and bladder cancer risk.

affected by some misclassification of tea consumption. Tea exposure is mostly assessed regarding the number of cups of tea consumed daily or weekly. However, cup size may vary considerably. Fourth, only eight studies performed analyses and reported the RR separately for black tea and green tea. All other studies referred simply to tea. Finally, studies included in our meta-analysis were mainly conducted in Europe, US, Canada, Uruguay, and Asia; therefore, we are not able to generalize our findings for all populations. Also, most studies just included bladder cancer without specifying the type. Transitional cell carcinoma is the most common type of cancer in these regions and we found no relevant papers

Table 2 Summary of pooled odds ratios (ORs)for bladder cancer by sex, geographical region, and tea type

\begin{tabular}{|c|c|c|c|c|c|}
\hline \multirow[t]{2}{*}{ Subgroup } & \multirow{2}{*}{$\begin{array}{l}\text { Number } \\
\text { of } \\
\text { studies }\end{array}$} & \multirow{2}{*}{$\begin{array}{l}\text { Pooled OR } \\
(95 \% \mathrm{Cl})\end{array}$} & \multirow{2}{*}{$\begin{array}{c}\begin{array}{c}\text { Q-test for } \\
\text { heterogeneity }\end{array} \\
\begin{array}{c}\text { P-value } \\
\left(I^{2} \text { score }\right)\end{array}\end{array}$} & \multirow{2}{*}{$\begin{array}{c}\begin{array}{c}\text { Egger } \\
\text { test }\end{array} \\
P \text {-value }\end{array}$} & \multirow{2}{*}{$\begin{array}{c}\begin{array}{c}\text { Begg } \\
\text { test }\end{array} \\
P \text {-value }\end{array}$} \\
\hline & & & & & \\
\hline All studies & 23 & $0.94(0.85,1.04)$ & $0.103(28.3 \%)$ & 0.518 & 0.267 \\
\hline \multicolumn{6}{|l|}{ Sex } \\
\hline Men & 10 & $1.03(0.91,1.14)$ & $0.534(0.0 \%)$ & 0.446 & 0.348 \\
\hline Women & 9 & $0.85(0.69,1.01)$ & $0.461(0.0 \%)$ & 0.638 & 0.348 \\
\hline \multicolumn{6}{|c|}{ Geographical region } \\
\hline Asia & 6 & $0.85(0.69,1.00)$ & $0.784(0.0 \%)$ & 0.360 & 0.348 \\
\hline Europe & 7 & $0.92(0.77,1.08)$ & $0.841(0.0 \%)$ & 0.789 & 0.881 \\
\hline Uruguay & 1 & $4.10(0.00,8.20)$ & - & - & - \\
\hline US/Canada & 9 & $1.02(0.83,1.21)$ & $0.008(61.2 \%)$ & 0.723 & 0.835 \\
\hline \multicolumn{6}{|l|}{ Tea type } \\
\hline Green tea & 5 & $0.97(0.73,1.21)$ & $0.793(0.0 \%)$ & 0.377 & 0.221 \\
\hline Black tea & 7 & $0.79(0.59,0.79)$ & 0.176 (33.1\%) & 0.381 & 0.764 \\
\hline
\end{tabular}

on squamous cell carcinoma. So the results are mainly based on transitional cell carcinoma but not squamous cell carcinoma.

\section{Conclusions}

In conclusion, in this pooled analysis of six cohort and seventeen case-control studies, we did not find that tea consumption was associated with decreased risk of bladder cancer. Given the small number of cohort studies included in this meta-analysis, further research from large epidemiological studies is needed in this area.

\section{Methods}

\section{Literature research}

We searched and reviewed the MEDLINE database using PubMed, Web of Science and the Cochrane Library, using selected common key words related to tea consumption and bladder cancer risk in case-control and cohort studies. We also scanned bibliographies of relevant articles in order to identify additional studies. As the key words for the literature search, we selected tea for the exposure factors, and bladder cancer for the outcome factors. The articles evaluating the relationship of urinary tract cancer and tea consumption were also retrieved, because the overwhelming majority of tumors occurred in the bladder, and the renal pelvis and ureter are covered by the same urothelium. The term bladder cancer was used as a synonym for these neoplasms.

Each identified publication was reviewed and included in the analysis if all the following criteria were met: first, they had to be case-control or cohort studies; second, papers reported in English between 1966 and December 2011; last, the result of each study was expressed as relative risk (RR) or odds ratio (OR) together with its 

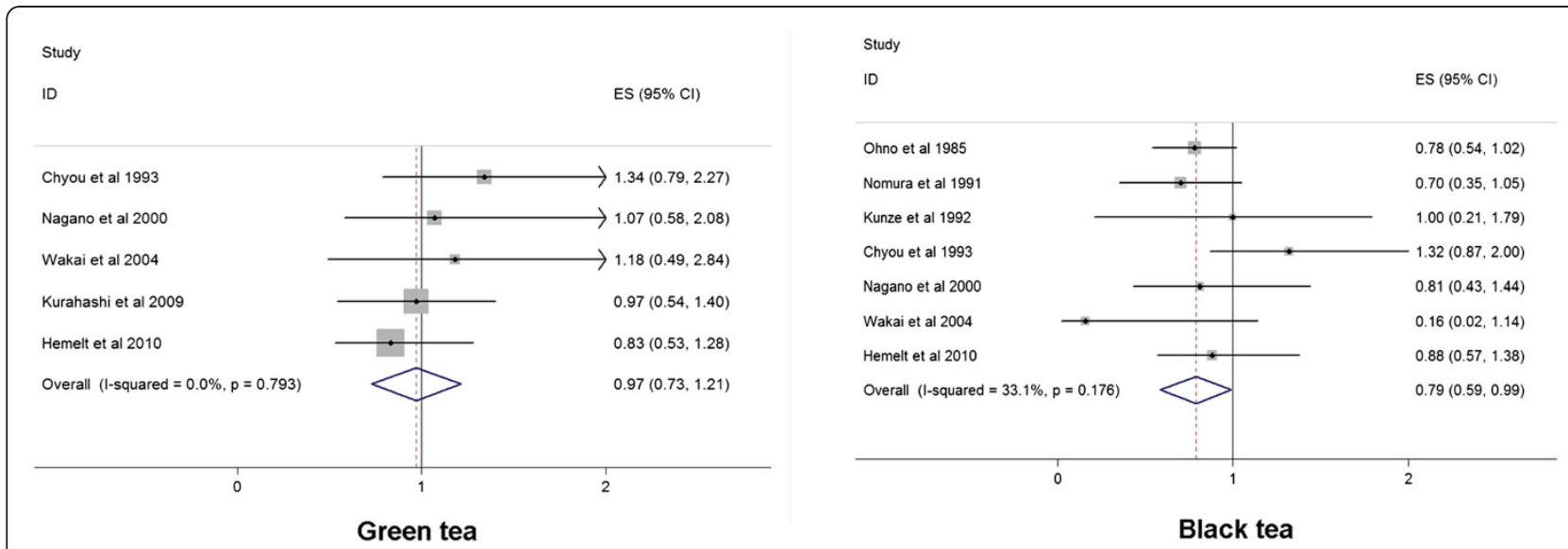

Figure 3 Forest plots showing the risk estimates from each study and the pooled risk estimates for green tea and black tea.

corresponding $95 \%$ confidence interval $(95 \% \quad \mathrm{CI})$ adjusted for age, sex and smoking at the least, or sufficient information allowing us to compute them.

\section{Data extraction}

Data from all articles were retrieved independently by JQ and QM while the methods and results sections were removed and coded to blind the assessors to this information. The following data were collected: the first author's name, the year of publication, country of origin, the study design (cohort or case-control), number of participants (cases and cohort size, or cases and controls), anatomical site of the neoplasm, adjusted effects estimates, exposure assessment and adjusted covariates. Considering that bladder cancer is a rare disease, the RR was assumed to be approximately the same as the OR, and the OR was used as the study outcome. Adjusted ORs were extracted directly from the original reports. If studies reported sex-stratified age- and smokingadjusted ORs, we calculated the overall age-, smokingand sex-adjusted OR by combining these estimates using the method of Mantel and Haenszel [43].

\section{Statistical analysis}

We pooled data using the DerSimonian and Laird random effects models [44], which considers both withinstudy and between-study variation. Subgroup analyses were performed according to sex (male or female), study design (cohort or case-control studies), the study location (US/Canada, Europe, Uruguay or Asia) and tea types (green tea, black tea). We quantified the extent of heterogeneity using the Q-test [44] and the $\mathrm{I}^{2}$ score [45], and $P<0.05$ was considered statistically significant. Publication bias was assessed using the tests of Egger [46] and Begg [47]. All statistical analyzes were performed using Stata Statistical Software, version 10.0.

\section{Abbreviations}

RR: relative risk; Cl: confidence interval; OR: odds ratio; NSAID: non-steroidal anti-inflammatory drug; EGCG: epigallocatechin-3-gallate; OH-BBN: N-(4hydroxybutyl)-N-bytyl-nitrosame.

\section{Competing interests}

The authors declare that they have no competing interests.

\section{Authors' contributions}

XZ and JQ conceived the study concept and participated in its design, data extraction, statistical analysis, manuscript drafting and editing. JQ and BX participated in the literature research, manuscript drafting and editing. QM participated in design and data extraction. DK participated in manuscript drafting, editing and statistical analysis. YWL conceived the study concept and participated in data analysis. All authors read and approved the final manuscript.

\section{Acknowledgements}

This study was supported by grants from the National Natural Science Foundation of China (Grant Number 30900552).

\section{Author details}

'Department of Urology, First Affiliated Hospital, Zhejiang University School of Medicine, Hangzhou 310003, Zhejiang Province, China. ${ }^{2}$ Department of Urology, Tongde Hospital of Zhejiang Province, Hangzhou 310003, Zhejiang Province, China.

Received: 17 March 2012 Accepted: 13 August 2012

Published: 25 August 2012

\section{References}

1. Jemal A, Siegel R, Xu J, Ward E: Cancer statistics, 2010. CA Cancer J Clin 2010, 60:277-300.

2. Lattouf JB: Chemoprevention in bladder cancer: What's new? Can UrolAssoc J 2009, 3:S184-S187.

3. Busby JE, Kamat AM: Chemoprevention for bladder cancer. J Urol 2006, 176:1914-1920.

4. Yang CS, Maliakal P, Meng X: Inhibition of carcinogenesis by tea. Annu Rev Pharmacol Toxicol 2002, 42:25-54.

5. Kemberling JK, Hampton JA, Keck RW, Gomez MA, Selman SH: Inhibition of bladder tumor growth by the green tea derivative epigallocatechin-3gallate. J Urol 2003, 170:773-776.

6. Zeegers MP, Tan FE, Goldbohm RA, van den Brandt PA: Are coffee and tea consumption associated with urinary tract cancer risk? A systematic review and meta-analysis. Int J Epidemiol 2001, 30:353-362.

7. Morgan RW, Jain MG: Bladder cancer: smoking, beverages and artificial sweeteners. Can Med Assoc J 1974, 111:1067-1070.

8. Simon D, Yen $\mathrm{S}$, Cole P: Coffee drinking and cancer of the lower urinary tract. J Natl Cancer Inst 1975, 54:587-591. 
9. Iscovich J, Castelletto R, Esteve J, Munoz N, Colanzi R, Coronel A, Deamezola I, Tassi V, Arslan A: Tobacco smoking, occupational exposure and bladder cancer in Argentina. Int J Cancer 1987, 40:734-740.

10. Howe GR, Burch JD, Miller AB, Cook GM, Esteve J, Morrison B, Gordon P, Chambers LW, Fodor G, Winsor GM: Tobacco use, occupation, coffee, various nutrients, and bladder cancer. J Natl Cancer Inst 1980, 64:701-713.

11. Pelucchi C, Negri E, Franceschi S, Talamini R, La Vecchia C: Alcohol drinking and bladder cancer. J Clin Epidemiol 2002, 55:637-641.

12. Demirel F, Cakan M, Yalcinkaya F, Topcuoglu M, Altug U: The association between personal habits and bladder cancer in Turkey. IntUro/Nephrol 2008, 40:643-647

13. Heilbrun LK, Nomura A, Stemmermann GN: Black tea consumption and cancer risk: a prospective study. Br J Cancer 1986, 54:677-683.

14. De Stefani E, Boffetta P, Ronco AL, Deneo-Pellegrini H, Acosta G Mendilaharsu M: Dietary patterns and risk of bladder cancer: a factor analysis in Uruguay. Cancer Causes Control 2008, 19:1243-1249.

15. La Vecchia C, Negri E, Franceschi S, D'Avanzo B, Boyle P: Tea consumption and cancer risk. Nutr Cancer 1992, 17:27-31

16. Nagano J, Kono S, Preston DL, Mabuchi K: A prospective study of green tea consumption and cancer incidence, Hiroshima and Nagasaki (Japan). Cancer Causes Control 2001, 12:501-508.

17. Hartge P, Hoover R, West DW, Lyon JL: Coffee drinking and risk of bladder cancer. J Natl Cancer Inst 1983, 70:1021-1026.

18. Slattery ML, Schumacher MC, West DW, Robison LM: Smoking and bladder cancer. The modifying effect of cigarettes on other factors. Cancer 1988, 61:402-408

19. Ohno Y, Aoki K, Obata K, Morrison AS: Case-control study of urinary bladder cancer in metropolitan Nagoya. Natl Cancer InstMonogr 1985, 69:229-234.

20. Jensen OM, Wahrendorf J, Knudsen JB, Sorensen BL: The Copenhagen case-control study of bladder cancer. II. Effect of coffee and other beverages. Int J Cancer 1986, 37:651-657.

21. Risch HA, Burch JD, Miller AB, Hill GB, Steele R, Howe GR: Dietary factors and the incidence of cancer of the urinary bladder. Am J Epidemiol 1988, 127:1179-1191.

22. Clavel J, Cordier S: Coffee consumption and bladder cancer risk. Int J Cancer 1991, 47:207-212.

23. Nomura AM, Kolonel LN, Hankin JH, Yoshizawa CN: Dietary factors in cancer of the lower urinary tract. Int J Cancer 1991, 48:199-205.

24. D'Avanzo B, La Vecchia C, Franceschi S, Negri E, Talamini R, Buttino I: Coffee consumption and bladder cancer risk. Eur J Cancer 1992, 28A:1480-1484.

25. Kunze E, Chang-Claude J, Frentzel-Beyme R: Life style and occupational risk factors for bladder cancer in Germany. A case-control study. Cancer 1992, 69:1776-1790.

26. Chyou PH, Nomura AM, Stemmermann GN: A prospective study of diet, smoking, and lower urinary tract cancer. Ann Epidemiol 1993, 3:211-216.

27. Bruemmer B, White E, Vaughan TL, Cheney $C L$ : Fluid intake and the incidence of bladder cancer among middle-aged men and women in a three-county area of western Washington. Nutr Cancer 1997, 29:163-168.

28. Lu CM, Lan SJ, Lee YH, Huang JK, Huang CH, Hsieh CC: Tea consumption: fluid intake and bladder cancer risk in Southern Taiwan. Urology 1999, 54:823-828

29. Michaud DS, Spiegelman D, Clinton SK, Rimm EB, Curhan GC, Willett WC, Giovannucci EL: Fluid intake and the risk of bladder cancer in men. N Engl J Med 1999, 340:1390-1397.

30. Bianchi GD, Cerhan JR, Parker AS, Putnam SD, See WA, Lynch CF, Cantor KP: Tea consumption and risk of bladder and kidney cancers in a population-based case-control study. Am J Epidemiol 2000, 151:377-383.

31. Nagano J, Kono S, Preston DL, Moriwaki H, Sharp GB, Koyama K, Mabuchi K: Bladder-cancer incidence in relation to vegetable and fruit consumption: a prospective study of atomic-bomb survivors. Int J Cancer 2000, 86:132-138.

32. Geoffroy-Perez B, Cordier S: Fluid consumption and the risk of bladde cancer: results of a multicenter case-control study. Int J Cancer 2001, 93:880-887.

33. Zeegers MP, Dorant E, Goldbohm RA, van den Brandt PA: Are coffee, tea, and total fluid consumption associated with bladder cancer risk? Results from the Netherlands Cohort Study. Cancer Causes Control 2001, 12:231-238.

34. Woolcott CG, King WD, Marrett LD: Coffee and tea consumption and cancers of the bladder, colon and rectum. Eur J Cancer Prev 2002, 11:137-145.
35. Wakai K, Hirose K, Takezaki T, Hamajima N, Ogura Y, Nakamura S, Hayashi N, Tajima K: Foods and beverages in relation to urothelial cancer: case-control study in Japan. Int J Urol 2004, 11:11-19.

36. De Stefani $E$, Boffetta $P$, Deneo-Pellegrini $H$, Correa P, Ronco AL, Brennan $P$, Ferro G, Acosta G, Mendilaharsu M: Non-alcoholic beverages and risk of bladder cancer in Uruguay. BMC Cancer 2007, 7:57.

37. Jiang X, Castelao JE, Groshen S, Cortessis VK, Shibata DK, Conti DV Gago-Dominguez M: Water intake and bladder cancer risk in Los Angeles County. Int J Cancer 2008, 123:1649-1656.

38. Kurahashi N, Inoue M, Iwasaki M, Sasazuki S, Tsugane S: Coffee, green tea, and caffeine consumption and subsequent risk of bladder cancer in relation to smoking status: a prospective study in Japan. Cancer Sci 2009, 100:294-291.

39. Hemelt M, Hu Z, Zhong Z, Xie LP, Wong YC, Tam PC, Cheng KK, Ye Z, Bi X, $L u Q$, et al: Fluid intake and the risk of bladder cancer: results from the South and East China case-control study on bladder cancer. Int J Cancer 2010, 127:638-645.

40. Ros MM, Bas Bueno-de-Mesquita HB, Buchner FL, Aben KK, Kampman E, Egevad L, Overvad K, Tjonneland A, Roswall N, Clavel-Chapelon F, et al: Fluid intake and the risk of urothelial cell carcinomas in the European Prospective Investigation into Cancer and Nutrition (EPIC). Int J Cancer 2011, 128:2695-2708.

41. Slattery ML, West DW, Robison LM: Fluid intake and bladder cancer in Utah. Int J Cancer 1988, 42:17-22.

42. Qin J, Xie LP, Zheng XY, Wang YB, Bai Y, Shen HF, Li LC, Dahiya R: A component of green tea, (-)-epigallocatechin-3-gallate, promotes apoptosis in T24 human bladder cancer cells via modulation of the $\mathrm{PI} 3 \mathrm{~K} / \mathrm{Akt}$ pathway and $\mathrm{Bcl}-2$ family proteins. Biochem Biophys Res Commun 2007, 354:852-857

43. Mantel N, Haenszel W: Statistical aspects of the analysis of data from retrospective studies of disease. J Natl Cancer Inst 1959, 22:719-748.

44. DerSimonian R, Laird N: Meta-analysis in clinical trials. Control Clin Trials 1986, 7:177-188.

45. Higgins JP, Thompson SG, Deeks JJ, Altman DG: Measuring inconsistency in meta-analyses. BMJ 2003, 327:557-560.

46. Egger M, Davey Smith G, Schneider M, Minder C: Bias in meta-analysis detected by a simple, graphical test. BMJ 1997, 315:629-634.

47. Begg CB, Mazumdar M: Operating characteristics of a rank correlation test for publication bias. Biometrics 1994, 50:1088-1101.

doi:10.1186/1477-7819-10-172

Cite this article as: Qin et al.: Tea consumption and risk of bladder cancer: a meta-analysis. World Journal of Surgical Oncology 2012 10:172.

\section{Submit your next manuscript to BioMed Central and take full advantage of:}

- Convenient online submission

- Thorough peer review

- No space constraints or color figure charges

- Immediate publication on acceptance

- Inclusion in PubMed, CAS, Scopus and Google Scholar

- Research which is freely available for redistribution 